\title{
The potential of yeasts from the oil-contaminated soil and mangrove rhizosphere for degrading crude oil
}

\author{
NUR HIDAYATUL ALAMI", LUTHFI LAILATUL MAULIDIYA, N.D. KUSWYTASARI, ENNY ZULAIKA, \\ MAYA SHOVITRI \\ Department of Biology, Faculty of Mathematics and Natural Sciences, Institut Teknologi Sepuluh Nopember. Jl. Raya ITS, Keputih, Sukolilo, Surabaya \\ 60111, East Java, Indonesia. Tel.: +62-31-5963857, Fax.: +62-31-5963857, `email: hidayatulalami@bio.its.ac.id.
}

Manuscript received: 7 February 2019. Revision accepted: 12 June 2019.

\begin{abstract}
Alami NH, Maulidiya LL, Kuswytasari ND, Zulaika E, Shovitri M. 2019. The potential of yeasts from the oil-contaminated soil and mangrove rhizosphere for degrading crude oil. Biodiversitas 20: 1833-1838. Bioremediation of crude oil contaminated soil eventually depends on the activities of microorganisms to degrade contaminants. Bioaugmentation, through the addition of microbial culture to contaminated soil, can be used to enhance degradation rates. This research aimed to determine the effect of yeast formulations isolated from the oil-contaminated soil and mangrove rhizosphere to degrade crude oil and evaluate the most effective yeast formulation and incubation timefor crude oil degradation. This research was conducted by subculturing yeast in the slant agar medium, screening hydrocarbonoclastic yeast in crude oil- Bushnell Hass Mineral Salt (BHMS) medium, biodegradation test, measuring the total cell number with Total Plate Count (TPC), Total Petroleum Hydrocarbon (TPH) test with the gravimetric method, and measuring soil moisture content. The design of the research was Completely Randomized Factorial Design with 3 replications. Data were analyzed quantitatively by using statistical tests for TPC and TPH, while a descriptive qualitative test analyzed soil moisture. The result showed that yeast formulation and incubation time affected crude oil degradation. An effective yeast consortium for oil degradation is T20 consortium with an incubation period of 30 days, which result in $72.26 \%$ oil degradation.
\end{abstract}

Keywords: Crude oil, degradation, mangrove rhizosphere, soil, yeast consortium

\section{INTRODUCTION}

Crude oil is the most important energy source in the world. Crude oil contains hydrocarbon complex which derived from fossils through a long process at high temperatures and pressures (Van Hamme et al. 2003; Abioye et al. 2013). Accidental spills during the exploration, production, refining, transport, and storage of this fossil hydrocarbon cause serious environmental problems (Romanus et al. 2015). The impact of this pollution is decreasing on soil fertility and water quality, blocking on aeration, inhibiting water absorption to the soil, changing soil texture (Ewetola 2013; Ying et al. 2013). According to Shafy and Mansour (2016), most of the hydrocarbons have toxic effects on humans, animals, and vegetation. It might cause a carcinogenic and mutagenic effect. Strategies to controloil contamination, including biological treatments, have been widely studied. Bioremediation provides the most cost-effective and ecofriendly measurements for the remediation of petroleum contaminated soil (Borah and Yadav 2016).

Microbial degradation is one of the foremost remediation mechanisms in the removal of oil from contaminated soil. Oil degradation is a complex process so that more than one isolate is needed to work together to accelerate the degradation process (Olajire and Essien 2014). The microbial consortium is a mix population of several different microbial isolates that are synergistic and can degrade pollutant compounds (Xenia and Refugio 2016). Microbial consortium might consist of indigenous or mixed with exogenous isolates. Mixed populations have the broad capacities required to degrade the complex mixtures of crude oil in the soil. The main principle of aerobic degradation of hydrocarbons depends on enzymatic key reactions catalyzed by oxygenases and peroxidases (Yuniati 2017).

Yeast is one of the microorganisms which has the enzymatic metabolism to reduce hydrocarbon compounds and utilize oil as carbon and energy source (Goulart et al. 2014). Yeast is found in soil and aquatic environments. Several studies stated that microorganisms, including yeast from oil-contaminated soils, are potential to degrade the oil. Meanwhile, marine yeast, that is distributed in almost every part of the aquatic environment,i.e., seawater, sediment, estuaries (including mangrove rhizosphere), etc.have been reported as agents of biodegradation. (Joko et al. 2012; Hassanshahiana et al. 2012; Geetha et al. 2013). Therefore, this research aimed to determine the influence of yeast formulation that was isolated from the oilcontaminated soil and mangrove rhizosphere and to obtain the most effective yeast formulation in crude oil degradation. 


\section{MATERIALS AND METHODS}

\section{Procedures}

Screening of hydrocarbonoclastic yeast

The pure culture of yeast was analyzed to evaluate its capability for degrading crude oil. The code of W.3.8, W.7.3, G.32, and G.4.1 were the isolates from isolated mangrove rhizosphere, while the code of PL, LD, SL, and OL were the isolates isolated from oil-contaminated soil. The liquid culture was started by adding a loop full of cells from Yeast Malt Extract Agar (YMEA) into $30 \mathrm{~mL}$ of Yeast Malt Extract Broth (YMEB). Then, isolates were incubated at $30^{\circ} \mathrm{C}$ under agitation $(90 \mathrm{rpm})$ for 48 hours until reach $\mathrm{OD} 0.5$ at $\lambda 600 \mathrm{~nm}$. After incubation completed, $1 \mathrm{~mL}$ of cultures were cultivated in $48 \mathrm{~mL}$ of Bushnell Hass Mineral Salt (BHMS) medium $\left(\mathrm{KH}_{2} \mathrm{PO}_{4} 1 \mathrm{~g}\right.$; $\mathrm{K}_{2} \mathrm{HPO}_{4} 0.2 \mathrm{~g} ; \mathrm{MgSO}_{4} .7 \mathrm{H}_{2} \mathrm{O} 0.2 \mathrm{~g} ; \mathrm{CaCl}_{2} 0.002 \mathrm{~g} ; \mathrm{NH}_{4} \mathrm{NO}_{3}$ 1g; two drops of $\mathrm{FeCl}_{3} 60 \% \mathrm{~L}^{-1}$ ) (Riskuwa-Shehu and Ijah 2016), then added with $1 \mathrm{~mL}$ of crude oil that was obtained from Public Oil Fields in Wonocolo Sub-district, Surabaya, Indonesia. Each culture was incubated again at $30{ }^{\circ} \mathrm{C}$ under agitation (90 rpm) for 7 days. The oil emulsion was observed on the 7 th day.

\section{Development of consortia of the selected yeast}

Different microbial consortia were designed as follows, (i) Combination of yeast isolates from mangrove rhizosphere composed of isolates W.3.8, W.7.3, G.32, and G.4.1 (encoded with R) with concentrations of $10 \%, 20 \%$, and $30 \%$ (encoded with 10, 20,30). (ii) Combination of yeast isolates from oil-contaminated soil composed of isolates PL, LD, SL and OL (encoded with T) with concentrations of $10 \%, 20 \%$, and $30 \%$ (encoded with 10 , 20, 30). (iii) Combination of yeast isolates from mangrove rhizosphere and oil contaminated soil (encoded with RT), and yeast concentration of $10 \%, 20 \%$, and $30 \%$ (encoded with 10, 20, 30). Control (encoded with $\mathrm{K}$ ) was added to this study as a set without yeast isolate.

\section{Biodegradation test}

Biodegradation test was carried out in soil reactor. Each formula was applied to $10 \mathrm{~g}$ of sterilized soil that has already added with $0.1 \mathrm{~mL}$ of crude oil, then incubated for 10 days, 20 days and 30 days. Every 10 days, yeast growth was assessed by measuring the number of yeast using Total Plate Count (TPC), while the Total Petroleum Hydrocarbon (TPH) was determined by the gravimetric method using nhexane as a solvent.

\section{Measurement of soil moisture content}

Soil moisture content was determined by taking out $5 \mathrm{gr}$ soil from the reactor then heating it in an oven at $105^{\circ} \mathrm{C}$ for 12 hours. The percentage of soil moisture content was calculated using the formulation below:

Percentage of soil moisture content $(\%)=\frac{W 2-W 3}{W 3-W 1} \times 100$
Where,

W1: weight of empty bottle (without cover) (g)

W2: weight of bottle with wet soil sample (without cover) $(\mathrm{g})$

W3: weight of bottle with dried soil sample (without cover) (g).

Growth of yeast cell during the biodegradation process

The number of yeast cell was measured by the method of Total Plate Count (TPC) on the YMEA medium. Measurements were carried out every 10 days during the incubation time. The following formula determined the total number of yeast cells:

Number of cells $(\mathrm{CFU} / \mathrm{g})=\frac{\text { Total colony } \mathrm{x} \text { dilution factor }}{\text { soil dried weight }}$

\section{Measurement of Total Petroleum Hydrocarbon (TPH)}

Total Petroleum Hydrocarbon (TPH) was determined by the gravimetric method, according to EPA $9071 \mathrm{~b}$ (1998). Ten grams of soil samples were dried in an oven at $40{ }^{\circ} \mathrm{C}$ for 10 minutes, then 10 grams of $\mathrm{Na}_{2} \mathrm{SO}_{4}$ (Sodium sulfate anhydrous) was added to remove water content. Samples were wrapped with filter paper and weighed to obtain the initial weight. The sample was put into the soxhlet extractor thimble. Extraction was carried out after the addition of $200 \mathrm{~mL}$-hexane. Soxhlet extractor was turned on until the vapor of $n$-hexane rises and reflux occurred (EPA 9071B 1998). The aqueous phase was removed by heating at $60^{\circ} \mathrm{C}$ (EPA 3630B 1996; Villalobos et al. 2008). The extraction products were placed in the desiccator containing silica gel to remove residual water (EPA 9071B 1998). The degree of biodegradation was calculated as follows (APHA, 1998):

Residues of oil $(\mathrm{mg} / \mathrm{g})=\frac{a-b}{a}$

Where,

$\mathrm{a}$ : Initial weight of soil $(\mathrm{g})$

b: The weight of soil after extraction $(\mathrm{g})$

Then the percentage of crude oil degradation is calculated, using the following formula:

Percentage of biodegradation $(\%)=\frac{(w o-w n)}{w o} \times 100 \%$

Where,

wo: initial amount of oil (mg/g)

wn: amount of oil after biodegradation $(\mathrm{mg} / \mathrm{g})$

\section{Data analysis}

Data were analyzed by descriptive quantitative using statistic test for Total Plate Count (TPC) and Total Petroleum Hydrocarbon (TPH), while a descriptive qualitative test analyzed the humidity. 


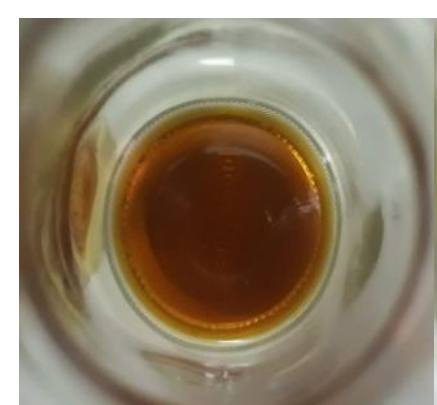

$\mathbf{A}$

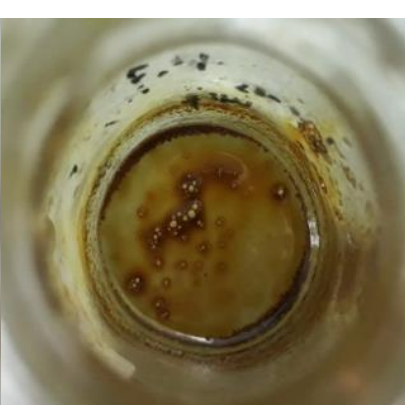

B

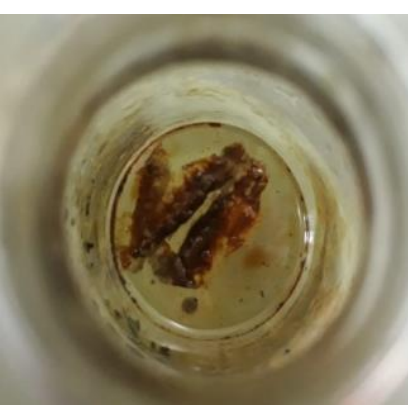

$\mathbf{C}$

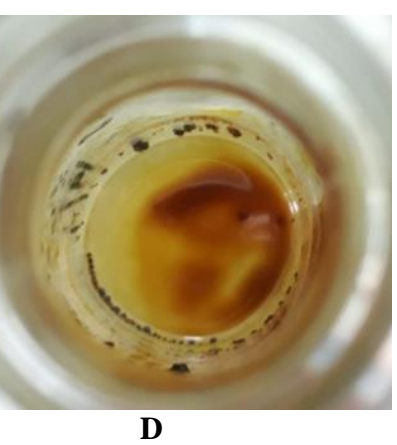

$\mathbf{D}$

Figure 1. Oil emulsification by several yeast isolates (W.7.3, PL, and G.3.2) compared to control (without yeast addition). A. Control, B. W.7.3, C. PL, D. G.3.2
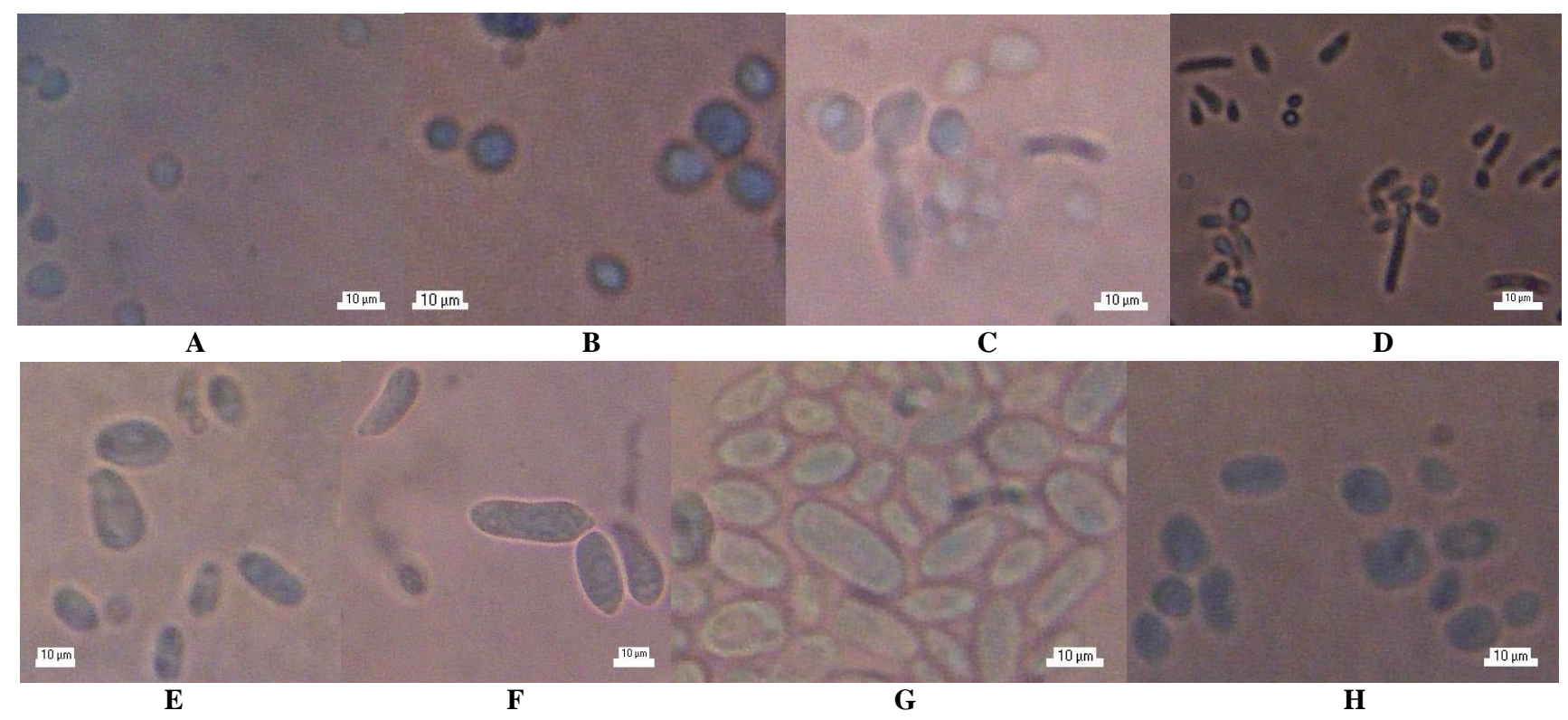

Figure 2. Microscopic morphology of yeast cell. Note: A. G.3.2, B. G.4.1, C. W.7.3, D. W.3.8, E. LD, F. OL, G. PL, H. SL. Bar=10 $\mu$ m

Table 1. Morphological characteristics of yeast isolates

\begin{tabular}{|c|c|c|c|c|c|c|c|c|}
\hline \multirow[b]{2}{*}{$\begin{array}{c}\text { Yeast } \\
\text { isolates }\end{array}$} & \multirow[b]{2}{*}{$\begin{array}{l}\text { Hydro- } \\
\text { lysis of } \\
\text { urea }\end{array}$} & \multirow[b]{2}{*}{ Colony color } & \multicolumn{5}{|c|}{ Fermentation of } & \multirow[b]{2}{*}{ Microscopic description } \\
\hline & & & 苍 & 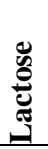 & 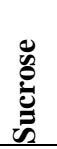 & 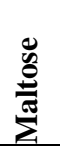 & $\frac{0}{\tilde{\sigma}_{0}}$ & \\
\hline G.3.2 & - & White & - & - & - & - & - & $\begin{array}{l}\text { Pseudohyphae is composed of long blastoconodia and parallel } \\
\text { lines. It resembles a "log in a stream". }\end{array}$ \\
\hline G.4.1 & + & Black & - & - & - & - & - & $\begin{array}{l}\text { Cells are round and oval in shape, have septate hyphae, and } \\
\text { produce black pigments. }\end{array}$ \\
\hline W.7.3 & - & White & + & - & - & - & - & $\begin{array}{l}\text { Single blastoconidia form a small union along the short and } \\
\text { curved pseudohyphae. There is a "Giant Cell." }\end{array}$ \\
\hline W.3.8 & - & $\begin{array}{l}\text { Greenish blue with } \\
\text { white edges }\end{array}$ & - & - & - & - & - & $\begin{array}{l}\text { Cells are oval and cylindrical. Pseudohyphae is formed from } \\
\text { blastoconidia which are long and sometimes chains. }\end{array}$ \\
\hline LD & - & Green & - & - & - & + & - & $\begin{array}{l}\text { Oval-shaped and elongated blastoconidia arranged like a short } \\
\text { chain. Have pseudohyphae and septate hyphae. }\end{array}$ \\
\hline $\mathrm{OL}$ & - & $\begin{array}{l}\text { White with orange } \\
\text { edges }\end{array}$ & - & - & - & - & - & $\begin{array}{l}\text { Oval-shaped with polar budding, have septate hyphae, and } \\
\text { pseudohyphae are formed. }\end{array}$ \\
\hline PL & - & $\begin{array}{l}\text { Green with white } \\
\text { edges }\end{array}$ & + & - & + & + & + & $\begin{array}{l}\text { Blastoconidia are oval, elongated, and curved shaped. Many } \\
\text { blastoconidia form the beginning pseudohyphae at the distal ends }\end{array}$ \\
\hline SL & - & Green & + & - & - & + & - & $\begin{array}{l}\text { There is clamidiospora terminalis. Circular blastoconodia form a } \\
\text { unity on the pseudohyphae. }\end{array}$ \\
\hline
\end{tabular}




\section{RESULTS AND DISCUSSION}

\section{Screening of hydrocarbonoclastic yeast}

The results showed that all of the isolates (G.3.2, G.4.1, W.7.3, W.3.8, LD, OL, PL, and SL) were positively emulsify the oil and could degrade the oil. (Figure 1.) Yeasts were characterized by morphological characters, and biochemical methods based on Kurtzman and Fell (1998) (Table 1). Microscopic morphology of yeast cell is shown in Figure 2.

\section{Number of yeast cell}

Based on Figure 3, the highest average number of yeast cells was in the T30 formulation in 30 days incubation time with the value of $6.489 \log$ CFU/g, followed by RT10 and T20 in 30 days incubation time with the value of $6.467 \mathrm{log}$ $\mathrm{CFU} / \mathrm{g}$ and $6.443 \mathrm{log} \mathrm{CFU} / \mathrm{g}$ respectively. Then to determine the effect of consortium type and incubation time on the number of yeast cells, statistical tests were performed. The results in Table 2 and Table 3 showed that there were significantly different amongst consortium types and incubation time in yeast cells number.

\section{Measurement of soil moisture content}

Measurements of soil moisture content were carried out to monitor soil water content in the reactor. Water content affects the onset of contamination, gas transfer, and the growth of microorganisms (Nugroho 2006). At the optimum moisture, microorganisms are active and grow faster. However, decreased water content causes limited movement of microorganisms and inhibited cell metabolism (Any and Fudhola 2011; Tchobanoglous 1993). The soil moisture content presented in Figure 4.

\section{Measurement of Total Petroleum Hydrocarbon (TPH)}

Based on the results of the gravimetric test, the oil content was decreased when compared to the initial oil concent in all treatments at different incubation times. It showed that the yeast consortium was able to degrade crude oil. The results also showed that the longer the incubation time, the more the decrease in oil content (Figure 5).

Figure 6 showed that T30 and RT10 were able to reduce the oil content up to $77.47 \%$ and $76 \%$ on day 30 , followed by RT20 and RT30 with degradation percentage of $74.01 \%$ and $72.28 \%$. Isolate T30 has the best ability to degrade oil because isolate $\mathrm{T}$ was isolated from soil contaminated with crude oil. $\mathrm{T}$ isolate also has a good ability to adapt to the media of oil-contaminated soil. $\mathrm{T}$ isolate also has the highest number of yeast cells. The results showed that almost all formulations except controls (K) were able to degrade crude oil more than $50 \%$ on day 30. It indicated that the yeast consortium was able to degrade Total Petroleum Hydrocarbon oil efficiently.

Based on the results, it was found that T30 on day 30 (H30) was significantly different in decreasing TPH from almost all treatments from day 0 to day 20 . However, on day 30, T30 was not significantly different from R20, R30, T10, T20, RT10, RT20, and RT30.

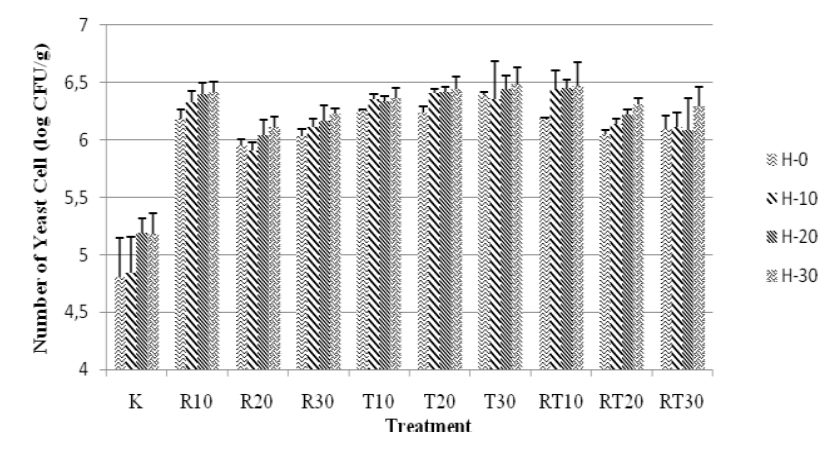

Figure 3. Number of yeast cells (log CFU/g) in different consortium types and incubation period. Note: K: Control (without yeast addition); R10: Consortium of rhizosphere yeast with a concentration of $10 \%$; R20: Consortium of rhizosphere yeast with concentration of $20 \%$; R30: Consortium of rhizosphere yeast with concentration of 30\%; T10: Consortium of yeast from oil-contaminated soil with a concentration of $10 \%$; T20: Consortium of yeast from oil-contaminated soil with a concentration of $20 \% \mathrm{~g}$ ). T30: Consortium of yeast from oilcontaminated soil with a concentration of $30 \%$; RT10: Consortium of rhizosphere yeast and yeast from oil-contaminated soil with a concentration of $10 \%$; RT20: Consortium of rhizosphere yeast and yeast from oil-contaminated soil with a concentration of 20\%; RT30: Consortium of rhizosphere yeast and yeast from oil-contaminated soil with a concentration of $30 \%$; H0: Day 0; H10: Day 10; H20: Day 20; H30: Day 30.

Table 2. The number of yeast cells in several consortium types

\begin{tabular}{lc}
\hline Treatment & $\begin{array}{c}\text { The average yeast cell number } \\
\text { (CFU/ g) }\end{array}$ \\
\hline K & $1.19 \times 10^{5 \mathrm{e}}$ \\
R10 & $2.22 \times 10^{6 \mathrm{~b}}$ \\
R20 & $1.04 \times 10^{6 \mathrm{~d}}$ \\
R30 & $1.41 \times 10^{6 \mathrm{~cd}}$ \\
T10 & $2.15 \times 10^{6 \mathrm{~b}}$ \\
T20 & $2.44 \times 10^{6 \mathrm{ab}}$ \\
T30 & $2.78 \times 10^{6 \mathrm{a}}$ \\
RT10 & $2.61 \times 10^{6 \mathrm{ab}}$ \\
RT20 & $1.55 \times 10^{6 \mathrm{c}}$ \\
RT30 & $1.51 \times 10^{6 \mathrm{c}}$
\end{tabular}

Note: The difference in notation behind the value indicates a significant difference $(\mathrm{p}<0.05)$

Table 3. Effect of incubation time on the number of yeast cells

\begin{tabular}{cc}
\hline Incubation time & $\begin{array}{c}\text { The average yeast cell number } \\
(\text { CFU/g) }\end{array}$ \\
\hline H0 & $1.35 \times 10^{6 \mathrm{c}}$ \\
H10 & $1.75 \times 10^{6 \mathrm{~b}}$ \\
H20 & $1.89 \times 10^{6 \mathrm{ab}}$ \\
H30 & $2.15 \times 10^{6 \mathrm{a}}$ \\
\hline
\end{tabular}

Note: The difference in notation behind the value indicates a significant difference 


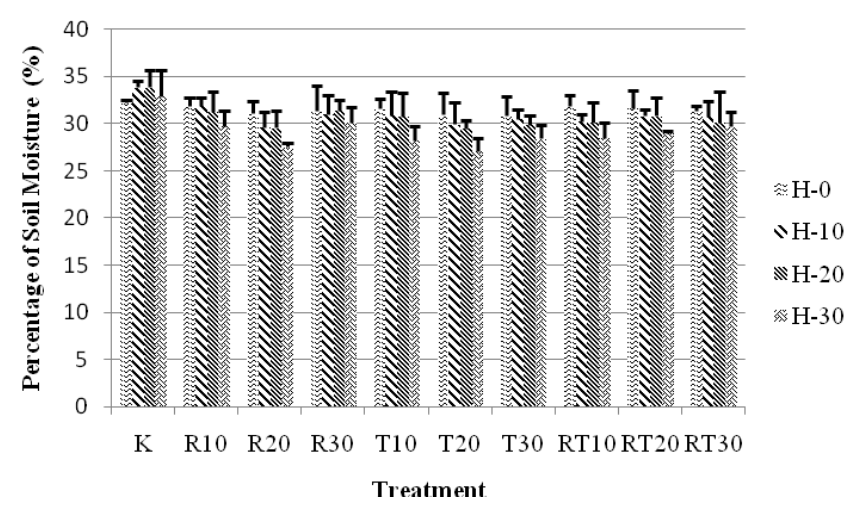

Figure 4. Percentage of soil moisture at different consortium types and incubation period

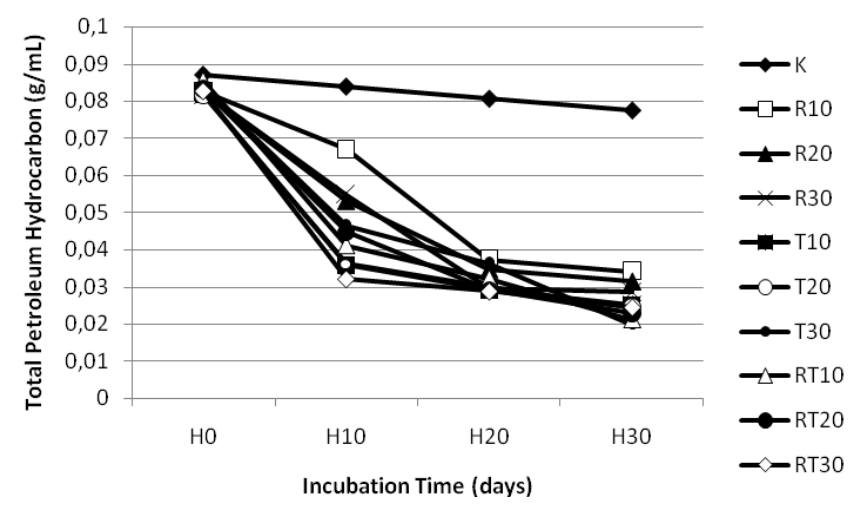

Figure 5. Total Petroleum Hydrocarbon (TPH) of different consortium types at different incubation period

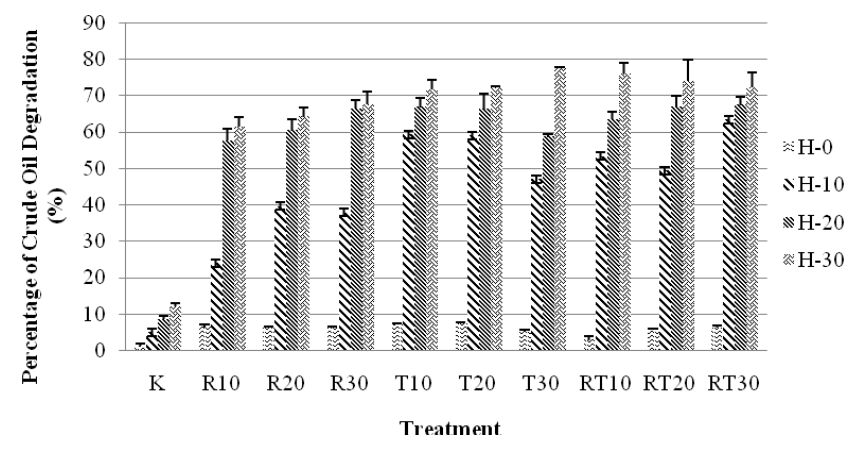

Figure 6. Percentage of crude oil degradation of different consortium types at different incubation period

\section{Discussion}

It is known that some yeasts can hydrolyze crude oil, this can be seen from the depletion of the crude oil layer in the liquid medium, the oil droplets are formed on the edge of the layer, and the medium becomes more turbid compared to the control. Depletion of the oil layer occurs due to the breakdown of the composition of crude oil (hydrocarbons) by yeast cells. Crude oil consists of complex hydrocarbon compounds. Based on the biodegradability of hydrocarbon can generally be ranked as follows: aliphatic hydrocarbon is generally easier to degrade than aromatic compounds, straight-chain aliphatic hydrocarbons are easier to degrade than branched-chain hydrocarbons, saturated hydrocarbons are more easily degraded than unsaturated hydrocarbons, and long-chain aliphatic hydrocarbons are more easily degraded than short-chain hydrocarbons (Baker and Herson 1994). Some of the studies reported that yeast could utilize a wide range of hydrocarbons, with a preference for alkanes with intermediate carbon chain lengths Increasing turbidity of the medium indicated the growth of microorganisms (Ristianti et al. 2016). Biodegradable materials can be used as a food source for the yeast cells, and in consequence, they grow and multiply (Baker and Herson 1994).

The T30 consortium has the best TPC value, which is not significantly different from the T20 and RT10 consortium but is significantly different from the control so that these consortia are potential candidates for oil degradation. The potential consortium can be combined with the incubation period to optimize oil degradation because the incubation period also affected the TPC value. The longer the incubation period showed an increase in the number of cells (Figure 3), which indicated as microbial cell growth Therefore it can be concluded that the yeast consortium can use oil as a carbon source. Cookson (1995) stated that hydrocarbons are used as sources of nutrients and energy sources by microbes. Furthermore, Nugroho (2006) stated that the abundance and diversity of microorganisms in nature has a positive correlation with the percentage of oil degradation.

Figure 4 showed that almost all treatments have optimum soil moisture content with an average of 25 34\%. According to Tchobanoglous (1993) and Nugroho (2006); the optimum range of moisture content in the degradation process for gas exchange ranges from 25 to $35 \%$. However, on the $30^{\text {th }}$ day of incubation time, it showed that moisture content in almost all treatments had been decreased. It was caused by evaporation due to stirring (aeration) every 7 days. According to Doerffer (1992), stirring can cause evaporation because the temperature in the soil reactor increases due to the degradation process so that when the soil is stirred, the water directly will evaporate out.

According to Zhu et al. (2001), oil can not only be degraded by a single isolate, but it can also be degraded by more than one microorganism in the form of a consortium. The mixture of isolates will produce more various enzymes and have a higher level of degradation compared to a single isolate so that it can degrade crude oil quickly (Nugroho 2006).

Aerobic degradation can start with the introduction of oxygen into carbon molecules by the oxygenase enzyme. $\mathrm{N}$-alkanes will be oxidized by the enzyme oxygenase to produce primary alcohol (Fritsche and Hofrichter 2000) which are subsequently oxidized to fatty acids and carboxylic acids by alcohol dehydrogenase and aldehyde dehydrogenase. Fatty acids will be converted to form intermediate compounds in the form of Acetyl CoA through the process of $\beta$-oxidation, then Acetyl CoA enters the tricarboxylic acid cycle to produce $\mathrm{CO}_{2}$ and $\mathrm{H}_{2} \mathrm{O}$ and 
the energy used by microorganisms to grow and develop (Xenia and Refugio 2016).

The success of the degradation process can be seen from the rate of biodegradation and the cost to achieve the largest of oil degradation percentage. Therefore, an effective and efficient degradation process starts with suitable microorganisms, which might consist of only a few isolates, but these isolates are capable of accelerating biodegradation rates.

In this study, it was determined that the most effective formulation in degrading crude oil is the T20 consortium with 30 days incubation period. This is because T20 produces degradation percentage that is not significantly different from T30 (the highest percentage of degradation) at lower concentrations The number of T20 isolates is less (consist of 4 isolates) when compared to RT10 (8 isolates), but the result of degradation of crude oil is not significantly different, so T20 has good prospects for bioremediation of crude oil contaminated soil. In addition, according to Doerffer (1992), increasing the number of isolates of the consortium can inhibit the degradation process due to the interaction between isolates in competing for nutrients.

\section{REFERENCES}

Abioye OP, Kinsola ROA, Aransiola SA, Darnisa D. 2013. Biodegradation of crude oil by Saccharomyces cerevisiae isolated from fermented zobo (locally fermented beverage in Nigeria). Pak J Biol Sci 16 (24): 2058-2061.

Any J, Fudhola R. 2011. Bioremediasi lumpur minyak (Oil Sludge) dengan penambahan kompos sebagai bulking agent dan sumber nutrisi tambahan. Jurnal Sains dan Teknologi Lingkungan 3 (1). [Indonesian]

APHA (American Public Health Association). 1998. Standard Methode for The Examination of Water and Waste Water. 20 the ed. American Water Works Association (AWWA) and Water Pollution Control Federatio (WPCF), Washington, DC.

Baker KH, Herson DS. 1994. Bioremediation.Mc-Graww-Hill Inc. Washington.

Borah D, Yadav RNS. 2016. Bioremediation of petroleum based contaminants with biosurfactant produced by a newly isolated petroleum oil degrading bacterial strain. Egypt J Pet 26: 181-188.

Cookson JT Jr. 1995. Bioremediation Engineering Design and Application. Mc.Graw Hill Inc., New York, USA

Doerffer JW. 1992. Oil Spill Response in The Marine Environment. Pergamon Press, New York, USA.

EPA Method 3630 B.1996. Silica gel cleanup. The United States Environmental Protection Agency, SW-846 Manual. US Government Printing Office. Washington, DC.

EPA Method 9071 B. 1998. n-hexane extractable material (HEM) for sludge, sediment, and solid samples. The United States Environmental Protection Agency, SW-846 Manual. US Government Printing Office. Washington, DC.

Ewetola EA. 2013. Effect of crude oil pollution on some soil physica properties. IOSR J Agric Vet Sci 6 (3): 14-17.
Fritsche W, Hofrichter M. 2000. Aerobic Degradation by Microorganisms. In: Rehm HJ, Reed G (eds). Biotechnology: Environmental Processes II 2008; 11b, 2nd ed. Wiley-VCH Verlag GmbH, Weinheim, Germany.

Geetha SJ, Sanket J, Shailesh K. 2013. Isolation and characterization of hydrocarbon-degrading bacterial isolate from oil-contaminated site. Elsevier, Nederlands.

Goulart GG, Coutinho JOPA, Monteiro AS, Siqueira EP, Santos VL. 2014. Isolation and characterization of gasoline - Degrading yeast from refined oil contaminated residues. J Bioremed Biodegrad 5: 214. DOI: $10.4172 / 2155-6199.1000214$.

Hassanshahiana M, Tebyanian H. Capello S. 2012. Isolation and characterization of two crude oil -degrading yeast strain, Yarrowia lipolytica PG-20 and PG-32 from Persian Gulf. Mar Pollut Bull 64: 1386-1391.

Kurtzman CP, Fell JW. 1998. The Yeasts: A Taxonomic Study. 4th ed. Elsevier. Amsterdam.

Nugroho A. 2006. Biodegradasi sludge minyak bumi dalam skala mikrokosmos: simulasi sederhana sebagai kajian awal bioremediasi land treatment. Makara Teknologi 10 (2): 82-89. [Indonesian]

Olajire AA, Essien JP. 2014. Aerobic degradation of petroleum component by microbial consortia. J Petroleum Environ Biotechnol 5: 5. DOI: $10.4172 / 2157-7463.1000195$

Prayitno J, Prisha R, Herlina S. 2012. Formulasi konsorsium mikroba asal pertambangan minyak Siak, Riau yang efektif dalam mendegradasi senyawa hidrokarbon. Jurnal Tek Ling 13 (2): 123-130. [Indonesian]

Riskuwa-Shehu ML, Ijah UJJ. 2016. 2016. Enhanced removal of crude oil in soil by mixed culture of Bacillus megaterium UL 50 and Pseudomonas aeruginosa UL07. Intl J Environ Bioremed Biodegrad 4 (1): 8-12.

Ristianti NP, Sanusi M, Putra MGP. 2016. Uji kemampuan degradasi minyak solar oleh konsorsium bakteri hasil preservasi dengan kombinasi metode liofilisasi dan metode gliserol. Prosiding Seminar Nasional MIPA 2016. Jurusan Pendidikan Biologi Universitas Pendidikan Ganesha, Singaraja. [Indonesian]

Romanus AA, Ikechukwu EF, Patrick AS, Goddey U, Helen O. 2015. Efficiency of plantain peel and Guinea corn shaft for bioremediation of crude oil polluted soil. J Microbiol Res 5: 31-40.

Shafy HIA, Mansour MSM. 2016. A review on polycyclic aromatic hydrocarbons: Source, environmental impact, effect on human health and remediation. Egypt J Petroleum 25: 107-123.

Tchobanoglous G, Theisen H, Vigil SA. 1993. Integrated Solid Waste Management. McGraw-Hill. New York.

Van Hamme, Singh JDA, Ward OP. 2003. Recent advances in petroleum microbiology. Microbial Mol Biol Rev. 67: 503-549.

Villalobos M, Avila-Forcada AP, Gutierrez-Ruiz ME. 2008. An improved gravimetric methode to determine total petroleum hydrocarbon in contaminated soil.Water Air Soil Pollut 194: 151-161.

Xenia ME, Refugio RV. 2016. Microorganisms metabolism during bioremediation of oil contaminated soil. J Bioremed Biodegrad 7: 2 . DOI: $10.4172 / 2155-6199.1000340$

Ying W, Feng J, Lin X, Xiaoyu W, Guoping W. 2013. Effect of crude oil contaminated on soil physical and chemical properties in Momoge Wetland of China. Chin Geogr Sci 23 (6): 708-715.

Yuniati, MD. 2017. Bioremediation of petroleum-contaminated soil: A Review. IOP Conf. Series: Earth Environ Sci 118 (2018) 012063.

Zhu X, Venosa AD, Suidan MT, Lee K. 2001. Guidelines for Bioremediation of Marine Shorelines and Freshwater Wetlands. U.S. Environmental Protection Agency, Office of Research and Development National Risk Management, Research Laboratory Land Remediation and Pollution Control Division, Cincinnati, $\mathrm{OH}$. 